\title{
Ammonia levels on in vitro degradation of fibrous carbohydrates from buffel grass
}

\author{
J.A. Santana Neto ${ }^{1}$, J.S. Oliveira ${ }^{2}$, C.J.B. Oliveira ${ }^{2}$, E.M. Santos ${ }^{2}$, E.C.B. Costa ${ }^{2}$, \\ C.A.S. Saraiva ${ }^{2}$ \& R.M.A. Pinho ${ }^{3 \#}$ \\ ${ }^{1}$ Universidade Federal de Sergipe, Av. Marechal Rondon, s/n, Jd. Rosa Elze. São Cristóvão - SE, Brazil \\ ${ }^{2}$ Universidade Federal da Paraíba, Centro de Ciências Agrárias, Campus II, Rodovia BR 079, Km 12, Areia - PB, Brazil \\ ${ }^{3}$ Universidade Federal do Maranhão, BR-222, KM 04, S/N, Boa Vista, Chapadinha, MA - Brazil
}

(Received 2 November 2018; Accepted 12 January 2019; First published online 23 June 2019)

\author{
Copyright resides with the authors in terms of the Creative Commons Attribution 4.0 South African License. \\ See: http://creativecommons.org/licenses/by/4.0/za \\ Condition of use: The user may copy, distribute, transmit and adapt the work, but must recognize the authors and \\ the South African Journal of Animal Science.
}

\begin{abstract}
This study was carried out to examine the degradation dynamics of neutral detergent fibre (NDF) and the profile of volatile fatty acids that originate from the fermentation of buffel grass (Cenchrus ciliaris, L.) with various levels of ammonia in the growth medium. The treatments consisted of six levels of ammonia in the growth medium $(0,5,10,15,20$ and $30 \mathrm{mg} / \mathrm{dL})$, which were obtained by adding urea. These in vitro incubation times were evaluated in three replicates per time for $0,3,6,9,12,24,36,48,72$ and 96 hours. Rumen concentrations of acetate and propionate responded quadratically to the ammonia levels. The treatment with $15 \mathrm{mg} / \mathrm{dL}$ of ammonia nitrogen in the rumen fluid provided mean acetate and propionate contents of $57.6 \mathrm{mM}$ and $23.1 \mathrm{mM}$, respectively. Urea addition elevated the degradation rate of potentially degradable fraction of NDF (pdNDF) from $2.5 \%$ to $20.1 \%$ in comparison with the treatment without urea and to a reduction in estimated discrete lag time from 0.34 to 2.31 hours. Urea supplementation increased the specific microorganism growth rate from $2.6 \%$ to $20.1 \%$. At the end of the incubation trial, NDF degradation showed a quadratic response, with maximum value obtained at $17.76 \mathrm{mg} / \mathrm{dL}$ of ammonia in the rumen fluid. Urea improves the degradation dynamics of NDF from deferred buffel grass and increases the concentrations of acetate and propionate.
\end{abstract}

Keywords: Cenchrus ciliaris, degradation kinetics, non-protein nitrogen, urea

\# Corresponding author: adelson@zootecnista.com.br

\section{Introduction}

Ammonia is one of the main compounds that are used by rumen microorganisms to degrade fibrous carbohydrates, and is essential for their growth. Supplementation of nitrogen sources to ruminants has shown to be an important practice, especially for animals that are reared on pasture (Figueiras et al., 2010). This strategy improves the digestibility of forage in the rumen, providing the animal with a greater uptake of energy and nutrients in the form of volatile fatty acids (VFA) and microbial protein.

In semi-arid regions, buffel grass is used widely in pastures for small ruminants (goats and sheep). During the drought period, in deferment systems, it is common to use buffel grass standing hay to feed the animals as a way to ensure the availability of herbage mass in sufficient amounts to meet the animals' intake requirement satisfactorily (Santos et al., 2005).

Buffel grass standing hay that is managed in deferment systems has low concentrations of lignin, total carbohydrates, total digestible nutrients, protein linked to acid detergent fibre (ADF) and NDF (Moreira et al., 2007). The main limitation of deferred buffel grass pastures is their protein content.

Efficient utilization of the fibrous fraction of forages, which can be achieved through the addition of nitrogenous compounds, leads to improved animal performance and greater productive and economic efficiency of production systems (Costa et al., 2008). Many studies have been carried out to determine the ruminal concentration of ammonia nitrogen $\left(\mathrm{NH}_{3}-\mathrm{N}\right)$ that is required to optimize the fermentation of fibrous carbohydrates by rumen microorganisms. However, this concentration is still controversial. Still, for tropical 
grasses, $10 \mathrm{mg}$ to $20 \mathrm{mg}$ ammonia $\mathrm{d} / \mathrm{L}$ rumen fluid are necessary to maximize rumen degradation and dry matter (DM) intake, respectively.

Nitrogenous compounds are known to be important for the digestion of fibrous carbohydrates in ruminants. However, most of these studies were conducted with cattle, and little research has been done on the ruminal concentration of $\mathrm{NH}_{3}-\mathrm{N}$ and forage degradation in goats. Cattle should not be considered experimental models in studies of NDF degradation for small ruminants, since differences in the composition of the microbial community are related mostly to the diet (Campos et al., 2006). Nevertheless, the host species can influence the structure of the bacterial community (Henderson et al., 2015).

In this way, to determine how goats best utilize the fibrous fraction of forages, forage digestion dynamics must be investigated using nitrogenous compounds in various proportions so that the extent of fibre degradation can be measured. Additionally, microbial growth and VFA production in the rumen must be examined.

This study proposes to evaluate the in vitro degradation dynamics of NDF fibre from low-quality buffel grass (Cenchrus ciliaris L.) with various levels of ammonia in the medium and growth profile of rumen microorganisms from goats.

\section{Material and Methods}

The in vitro trial was carried out at the Laboratory of Forage Crops of the Department of Animal Science, Centre for Agrarian Sciences, Federal University of Paraíba (UFPB), Areia - PB, Brazil. A rumenfistulated goat was used as a donor of rumen fluid. The goat was fed elephant grass solely for seven consecutive days prior to rumen fluid collection to reduce the concentration of nitrogenous compounds in the rumen fluid.

The experiment was undertaken in accordance with biosafety and ethics norms and was approved by the Ethics Committee in Animal Use (CEUA) of the Centre for Biotechnology (CBiotec) at UFPB (approval no. 0209/14).

Buffel grass (Cenchrus ciliaris) was collected from a deferred pasture, in which the grass was in an advanced physiological stage of growth. The grass was dried in a forced-air oven $\left(60^{\circ} \mathrm{C}\right)$ and ground in a knife mill with 2-mm sieves to be used in the incubations and in a knife mill with 1-mm sieves to quantify the concentrations of DM (method 930.15), crude protein (CP) (method 968.06), ether extract (EE) (954.05) and mineral matter (MM) (ash) (method 942.05), as proposed by AOAC (2012). NDF, ADF and lignin contents were estimated by the methodology of Van Soest (1967) and were expressed corrected for ash and nitrogenous compounds. Neutral detergent insoluble nitrogen (NDIN) was expressed relative to total nitrogen (TN), (NDIN/TN), following the procedures described by Licitra et al. (1996). Total carbohydrates (TC) were obtained by the following equation:

$$
\mathrm{TC}(\%)=100-(\% \mathrm{CP}+\% \mathrm{EE}+\% \mathrm{MM}) .
$$

Non-fibrous carbohydrates (NFC) were calculated as:

$$
\mathrm{NFC}=100-(\% \mathrm{CP}+\% \mathrm{NDFap}+\% \mathrm{MM}+\% \mathrm{EE}),
$$

where NDFap is NDF that is free of ash and protein, as described by Sniffen et al. (1992) (Table 1).

Rumen fluid was collected from the goat three hours after the first feed supply to obtain inoculum that contained an active microbial population (Oliveira et al. 2012). In the laboratory, the fluid was saturated with carbon dioxide $\left(\mathrm{CO}_{2}\right)$ and left to rest at $39^{\circ} \mathrm{C}$. After the fluid interfaces were formed, the intermediate fluid was removed and centrifuged at $500 \times \mathrm{g}$ for $10 \mathrm{~min}$ and the supernatant was discarded to obtain inoculum that contained active microbial populations (Russell \& Martin 1984). The residue from centrifugation (pellet) was resuspended another two times in autoclaved McDougall buffer $(9.80 \mathrm{~g}$ of sodium bicarbonate $\left(\mathrm{NaHCO}_{3}\right) ; 4.65 \mathrm{~g}$ of disodium phosphate $\left(\mathrm{Na}_{2} \mathrm{HPO}_{4} .2 \mathrm{H}_{2} \mathrm{O}\right) ; 0.57 \mathrm{~g}$ of potassium chloride $(\mathrm{KCl}) ; 0.12 \mathrm{~g}$ of magnesium sulphate $\left(\mathrm{MgSO}_{4} .7 \mathrm{H}_{2} \mathrm{O}\right)$; and $0.04 \mathrm{~g}$ of calcium chloride $\left(\mathrm{CaCl}_{2}\right)$, diluted with distilled water up to the volume of $1000 \mathrm{~mL}$ ).

For each incubation bottle, $35 \mathrm{~mL}$ of the growth medium ( $28 \mathrm{~mL}$ McDougall buffer and $7 \mathrm{~mL}$ inoculum), $350 \mathrm{mg}$ buffel grass, or only $35 \mathrm{~mL}$ of the growth medium (blank) were used. Urea was added to the incubation bottles to attain the pre-established final concentrations of $\mathrm{NH}_{3}-\mathrm{N}$ in the growth medium of each treatment. The treatments had these compositions: i) $0 \mathrm{mg}$ urea, ii) $3.19 \mathrm{mg}$ urea, iii) $6.39 \mathrm{mg}$ urea, iv) 9.58 mg urea, v) $12.77 \mathrm{mg}$ urea and vi) $19.16 \mathrm{mg}$ urea. Each bottle was then saturated with $\mathrm{CO}_{2}$, capped, and sealed. Bottles were incubated at $39{ }^{\circ} \mathrm{C}$ in a BOD incubator for 96 hours. During incubation, the gases that were produced were removed from all bottles using syringes every 3 hours. 
Table 1 Chemical composition of buffel grass and urea (dry matter basis)

\begin{tabular}{lcc}
\hline Item & Buffel grass & Urea \\
\hline Dry matter ${ }^{1}(g / k g)$ & 854.4 & 982.1 \\
Organic matter (g/kg DM) & 905.2 & 997.6 \\
Ash $(g / k g ~ D M)$ & 94.8 & 2.4 \\
Crude protein (g/kg DM) & 49.8 & 2610.0 \\
Ether extract (g/kg DM) & 16.6 & - \\
Total carbohydrates (g/kg DM) & 838.8 & - \\
NDF (g/kg DM) & 857.0 & - \\
NDFap (g/kg DM) & 799.7 & - \\
ADF (g/kg DM) & 348.1 & - \\
NFC (g/kg DM) & 39.1 & - \\
TN (g/kg DM) & 8.0 & - \\
NDIN (\% of TN) & 195.6 & - \\
Lignin (g/kg DM) & 76.6 & -
\end{tabular}

${ }^{1}$ Based on a fresh matter basis; DM: dry matter; NDF: neutral detergent fibre; NDFap: neutral detergent fibre correct for ash and protein; ADF: acid detergent fibre; NFC: non-fibrous carbohydrates; TN: total nitrogen; NDIN, neutral detergent insoluble nitrogen

The experiment consisted of six levels of $\mathrm{NH}_{3}-\mathrm{N}(0 \mathrm{mg}, 5 \mathrm{mg}, 10 \mathrm{mg}, 15 \mathrm{mg}, 20 \mathrm{mg}$ and $30 \mathrm{mg} / \mathrm{dL}$ ), which were obtained through the addition of urea AR (Dinâmica, Ltd.) to the incubation medium and were incubated for $0,3,6,9,12,24,48,72$ and 96 hours. Each treatment had three replicates per time, in which the authors determined the in vitro degradation of NDF and microbial growth parameters. Three bottles without inoculum were included in the incubations, which served as blanks for degradability.

At the end of each incubation time, the bottles were removed from the BOD incubator and the residue was filtered to determine NDF degradability. A 2.0-mL sample of growth medium was collected from each experimental unit, placed in Eppendorf tubes, and centrifuged in a microcentrifuge at $5200 \times g$ for 10 min. The supernatant was then frozen for later analysis of the concentration of $\mathrm{NH}_{3}-\mathrm{N}$. The pellet was resuspended in $\mathrm{NaCl}$ solution $(0.9 \% \mathrm{w} / \mathrm{v})$ and centrifuged at $5200 \times \mathrm{g}$ for $10 \mathrm{~min}$, the supernatant was discarded, and the pellet was resuspended in $\mathrm{NaCl}$ solution $(0.9 \% \mathrm{w} / \mathrm{v})$ and frozen for later determination of microbial protein. The ammonia concentration was determined by the colorimetric method described by Chaney \& Marbach (1962), whereas the microbial protein content was obtained following the method of Bradford (1976).

For the analysis of VFA, at 48 hours of incubation, a 2.0-mL sample of growth medium was collected from all experimental units, placed in Eppendorf tubes, and centrifuged at $5200 \times g$ in a microcentrifuge for $10 \mathrm{~min}$. The supernatant was then frozen in a high-performance liquid chromatograph (Shimadzu, SPD-10A VP) coupled to an ultraviolet detector operating at a wavelength of $210 \mathrm{~nm}$. A C18 column (Shimadzu) with $30 \mathrm{~cm} \times 7.9 \mathrm{~mm}$ diameter and $0.6 \mathrm{~mL} / \mathrm{min}$ flow was used under a pressure of $69 \mathrm{kgf}$, with the water mobile phase in $1 \%$ orthophosphoric acid and injected volume of $20 \mu \mathrm{L}$. Concentrations of acetate, propionate and butyrate, acetate/propionate ratio, total VFA and lactate concentrations were measured.

The bottles that were considered blank, that is, that contained the incubation solutions without substrate, were also incubated to adjust the variations. The bottles were closed with rubber corks and agitated to homogenize the samples.

To determine NDF degradability, for each period, the residual material from each bottle was collected and washed with warm water in a filtering crucible until the growth medium was removed. This residue was dried in an air oven and, 24 hours later, weighed on an analytical scale. The NDF content, which was considered the indigestible part of the feed, was determined in this residue by the method of Van Soest (1967).

The NDF residues at the various times for each treatment were analysed by the Gauss-Newton algorithm and adjusted to the non-linear logistic model described by Van Milgen et al. (1991) and Detmann et al. (2011). 
(I)

$$
R t=\mathrm{Ux} \frac{[\mathrm{c} \times \exp (-\mathrm{p} \times \mathrm{t})-\mathrm{p} \times \exp (-\mathrm{c} \times \mathrm{t})]}{(\mathrm{c}-\mathrm{p})}+I
$$

where: $\mathrm{Rt}=$ undegraded NDF residue at time " $\mathrm{t}$ " (\%)

$U=$ potentially degradable fraction of NDF (pdNDF) (\%)

$\mathrm{I}=$ undegradable fraction of NDF (iNDF) (\%)

$c=$ fractional rate of degradation of pdNDF $(/ \mathrm{h})$

$\mathrm{p}=$ fractional rate of lag time $(/ \mathrm{h})$

$\mathrm{t}=$ time $(\mathrm{h})$

The function described in (I) is considered symmetrical in relation to the fractional degradation rates $c$ and $p$, the lowest values of which are frequently known to be associated with c (Vieira et al., 1997). However, when the fractional rates $c$ and $p$ tend towards the same estimate, mathematical indeterminacy will be observed, and the model should be re-parameterised, according to the L'Hôspital's rule (Van Milgen et al., 1991):

(II)

$$
R t=\mathrm{U} \times(1+\lambda \mathrm{xt}) \mathrm{x} \exp (-\lambda x t)+I
$$

where: $\lambda=$ combined fractional rate of lag time and degradation $(/ \mathrm{h})$.

In this situation, because parameter $\lambda$ simultaneously describes the lag time and degradation rates, the fractional rate of degradation was determined from $\lambda$, using the gamma-2 distribution properties (Ellis et al. 1994):

(III)

$$
c^{\prime}=0.59635 \times \lambda
$$

where: $c^{\prime}=$ fractional rate of degradation of $\operatorname{pdNDF}(/ \mathrm{h})$ for the cases in which the re-parameterised model is used (Equation II).

Discrete lag time was obtained following the models of Vieira et al. (1997):

$$
L=\frac{R(0)-R(t i)}{\mu}+t i
$$

where: $L=$ discrete lag time $(h)$

$\mathrm{R}(0)=$ undegraded NDF residue at $\mathrm{t}=0(\%)$

$\mathrm{R}(\mathrm{ti})=$ undegraded NDF residue obtained at the inflection point of the degradation (\%)

$\mu=$ derivative of the degradation curve adjusted to the inflection point (maximum rate of degradation of the substrate) $(/ \mathrm{h})$

$t i=$ time corresponding to the inflection point of the degradation curve (h).

The ti values were calculated according to the observations of Van Milgen et al. (1991) (equations I and II, respectively):

(V)

$$
t i=\frac{\operatorname{In}(c)-\operatorname{In}(p)}{(\mathrm{c}-\mathrm{p})}
$$

(VI)

$$
t i=\frac{1}{\lambda}
$$

The specific microbial growth rate in relation to pdNDF was calculated in accordance with the hypothesis proposed by Beuvink \& Kogut (1993):

$$
S g r=\frac{\mu}{\mathrm{U}}
$$

where: SGR = specific microbial growth rate $(/ \mathrm{h})$.

After the SGR estimates had been obtained, the microbial growth efficiencies in relation to pdNDF were estimated by following the theories of Pirt (1965):

$$
\frac{1}{Y}=\frac{m}{\operatorname{Sgr}}+\frac{1}{Y m}
$$


(VIII)

where: $\mathrm{Y}=$ microbial efficiency ( $\mathrm{g}$ cells/g degraded carbohydrates)

$\mathrm{m}=$ requirement for the maintenance of microorganisms ( $\mathrm{g}$ carbohydrates $/ \mathrm{g}$ cells $/ \mathrm{h}$

$\mathrm{Ym}=$ theoretical maximum efficiency of the microorganisms on the substrate ( $\mathrm{g}$ cells $/ \mathrm{g}$ degraded carbohydrates).

The Ym parameter was adopted as reference, with the value of $0.4 \mathrm{~g}$ cells $/ \mathrm{g}$ degraded carbohydrates, while $\mathrm{m}$ was set as $0.05 \mathrm{~g}$ carbohydrates $/ \mathrm{g}$ cells $/ \mathrm{h}$, as recommended by Russell et al. (1992).

The effectively degraded fractions of NDF were calculated as proposed by Costa et al. (2008), in an adjusted version of the methodology described by Ørskov \& McDonald (1979):

(IX)

$$
E D F=\lim t \rightarrow \infty \int_{0}^{t}\left[\left(f(t) \times\left(-\frac{d R t}{d t}\right)\right] d t\right.
$$

where: $E D F=$ effectively degraded fraction of NDF (\%)

$f(t)=$ function relative to the displacement flow of solids in the rumen environment.

To define the function described in (IX), the authors assumed ruminal displacement flow of solids with gamma-1 distribution (Ellis et al. 1994), to which the hypothetical values of $0.020,0.035$ and 0.050 were allocated.

In this way, in the context of the equations $(X)$, EDF was calculated as follows:

$$
E D F=\mathrm{U} \times \frac{\lambda^{2}}{(\lambda+\mathrm{k})^{2}}
$$

The models were fitted to the degradation profiles as a function of the various addition levels and were compared descriptively. The $\mathrm{NH}_{3}-\mathrm{N}$ and microbial protein concentrations obtained at the incubation times of 0 hours and 48 hours were evaluated by variance and regression analyses. The criteria used in the choice of the model were the significance of regression coefficients at $5 \%$ probability by Tukey's test and the determination coefficient $\left(r^{2}\right)$, which was obtained as the sum of regression squares divided by the sum of squares of treatments and biological phenomenon.

VFA and lactate data were subjected to variance and regression analyses. The criteria for the choice of the regression models were the significance of the regression parameters, determination-coefficient values and the biological interpretation of the regression curves. The variables were analysed statistically by Tukey's test, and thus the regression analysis was applied for those that were significant.

The asymptotic standard deviation (ASD) was calculated from the root mean residual square of each model. All statistical analyses were performed with SAS software (Statistical Analysis System).

\section{Results}

The addition of urea elevated the $\mathrm{NH}_{3}-\mathrm{N}$ values linearly $(P<0.05)$, both at 0 hours (immediately after urea addition) and at 48 hours of incubation (Table 2). The analysis of the experimental time of 0 hours revealed that the lowest $\mathrm{NH}_{3}-\mathrm{N}$ value $(1.63 \mathrm{mg} / \mathrm{dL})$ was found in the treatment without urea addition, whereas this variable increased linearly up to the maximum value of $11.8 \mathrm{mg} / \mathrm{dL}$ in the treatment with maximum urea addition.

At 48 hours of incubation, an elevated concentration of $\mathrm{NH}_{3}-\mathrm{N}$ was observed in the medium, regardless of the concentration of urea added at 0 hours.

The microbial protein content (Figure 1b) rose alongside the release of ammonia (Figure 1a) in the medium, demonstrating that higher $\mathrm{NH}_{3}-\mathrm{N}$ levels provided greater microbial growth. After 12 hours of incubation, a peak of microbial protein was observed in the medium that contained $5 \mathrm{mg}$ to $30 \mathrm{mg} \mathrm{NH} \mathrm{N}_{3} \mathrm{~N} / \mathrm{dL}$. At the level of $0 \mathrm{mg} / \mathrm{dL}$, the peak concentration of microbial protein occurred between 72 hours and 96 hours of incubation. Throughout the incubation period, the ammonia and microbial protein concentrations in the medium were lower at $0 \mathrm{mg} \mathrm{NH}-\mathrm{N} / \mathrm{dL}$ than in the treatments that contained 5 to $30 \mathrm{NH}_{3}-\mathrm{N}$.

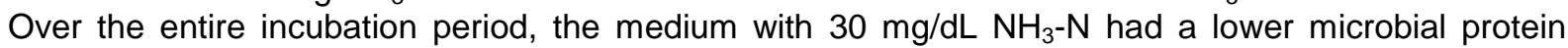
concentration than the media that contained $5 \mathrm{mg}$ to $20 \mathrm{mg} / \mathrm{dL}$ ammonia nitrogen (Figure $1 \mathrm{~b}$ ).

The ruminal concentrations of acetate and propionate responded quadratically $(P<0.05)$ to the treatments. The highest acetate $(57.6 \mathrm{mM})$ and propionate $(23.1 \mathrm{mM})$ values were obtained with $16.4 \mathrm{mg}$ to $15 \mathrm{mg} / \mathrm{dL}$ in the medium, respectively (Table 3). When the ammonia nitrogen concentrations exceeded these limits, fermentation decreased, generating a decline in the concentration of the said VFA. 
Table 2 Mean $( \pm$ SE) of ammonia nitrogen levels on concentrations of ammonia $(\mathrm{mg} / \mathrm{dL})$ and microbial protein $(\mathrm{mg} / \mathrm{dL})$ at 0 and 48 hours of in vitro incubation

\begin{tabular}{|c|c|c|c|c|c|c|c|c|c|c|}
\hline \multirow{2}{*}{ Indices } & \multicolumn{6}{|c|}{ Ammonia nitrogen (mg/dL) } & \multirow{2}{*}{ SEM $^{1}$} & \multirow{2}{*}{$r^{2}$} & \multicolumn{2}{|c|}{ P-value } \\
\hline & 0 & 5 & 10 & 15 & 20 & 30 & & & $\mathbf{L}$ & Q \\
\hline \multicolumn{11}{|c|}{$\mathrm{NH}_{3}-\mathrm{N}(\mathrm{mgdL})$} \\
\hline$O \mathrm{~h}^{2}$ & 1.63 & 3.47 & 7.12 & 7.87 & 8.56 & 11.81 & 1.32 & 0.94 & 0.018 & ns \\
\hline $48 h^{3}$ & 16.38 & 16.46 & 19.46 & 25.55 & 34.99 & 42.68 & 4,17 & 0.94 & 0.013 & ns \\
\hline \multicolumn{11}{|c|}{ Microbial protein (mg/dL) } \\
\hline $\mathrm{Oh}$ & 282.1 & 282.6 & 273.0 & 284.0 & 277.3 & 268.3 & 31.59 & - & ns & ns \\
\hline $48 h^{4}$ & 308.7 & 334.9 & 335.9 & 421.6 & 478.8 & 357.8 & 58.58 & 0.64 & 0.001 & 0.005 \\
\hline
\end{tabular}

${ }^{1}$ SEM: standard error mean, significant at the $5 \%$ probability level $(P<0.05$ by Tukey's test); NS: not significant;

L: linear; Q: quadratic, $\mathrm{r}^{2}$ : determination coefficient

${ }^{2} \hat{Y}=2.34+0.330 X ;{ }^{3} \hat{Y}=12.96+0.97 X ;{ }^{4} \hat{Y}=283.66+14.53 X-0.38 X^{2}$

No significant effects were observed $(P>0.05)$ for butyrate and lactate across the various concentrations of rumen ammonia nitrogen. The mean values for these acids were $2.5 \mathrm{mM}$ and $0.35 \mathrm{mM}$ (Table 3).

The acetate/propionate ratio was not affected significantly $(P>0.05)$ by the addition of urea to the ruminal medium, averaging $3.5 \mathrm{mM}$ of acetate for every millimolar unit of propionate. Total VFA production responded quadratically $(P<0.05)$, with maximum concentration obtained at the rumen ammonia nitrogen level of $14.5 \mathrm{mg} / \mathrm{dL}$ in the medium. Different results were found by Mehrez et al. (1977), who recommended $23 \mathrm{mg} / \mathrm{dL}$ in the rumen fluid for maximum fermentation in sheep. In the present study, the values for maximum fermentation were lower than those recommended by those authors.

Urea did not affect the $\mathrm{pH}$ of the rumen fluid at the experimental time of 0 hours $(P<0.05)$, when it averaged 6.83 (Table 4). After 48 hours of incubation, the $\mathrm{pH}$ values decreased linearly $(P<0.05)$ as urea was added to the rumen incubation medium, with values ranging from 7.64 to 7.33 . Accordingly, all the observed values were above the minimum recommended for the activity of fibrolytic enzymes, which is 6.0 (Mould et al., 1983; Cysneiros et al., 2013).

The use of non-protein nitrogen (NPN) increased the degradation rate of pdNDF by $2.5 \%$ to $20.1 \%$ in comparison with the treatment without NPN. The treatment with the addition of $15.0 \mathrm{mg} / \mathrm{dL}$ of ammonia nitrogen in the rumen fluid showed the best fractional rate of degradation obtained from the conversion of parameter $\lambda$.

Lower degradation of pdNDF and increased lag time were observed at the ammonia nitrogen concentration of $30.0 \mathrm{mg} / \mathrm{dL}$ compared with the treatments that contained 15.0 and $20 \mathrm{mg} / \mathrm{dL}$. The lower degradation of pdNDF at the ammonia nitrogen concentration of $30.0 \mathrm{mg} / \mathrm{dL}$ is due to excess ammonia in the medium, which inhibited microbial growth (Table 2; Figure 1).

The availability of ammonia nitrogen in the incubation medium increased linearly $(P<0.05)$ with the addition of an NPN source, namely urea (Table 7). The mean rumen ammonia nitrogen values observed in all treatments were higher than the minimum of 4 to $5 \mathrm{mg} / \mathrm{dL}$ that is recommended by Satter \& Slyter (1974) and were also higher than the approximate $10 \mathrm{mg} / \mathrm{dL}$ that is recommended by Van Soest (1994). The exception was the treatment with $0 \mathrm{mg} / \mathrm{dL}$ of ammonia nitrogen, which generated adequate values for microbial growth on fibrous carbohydrates and NDF degradation. 


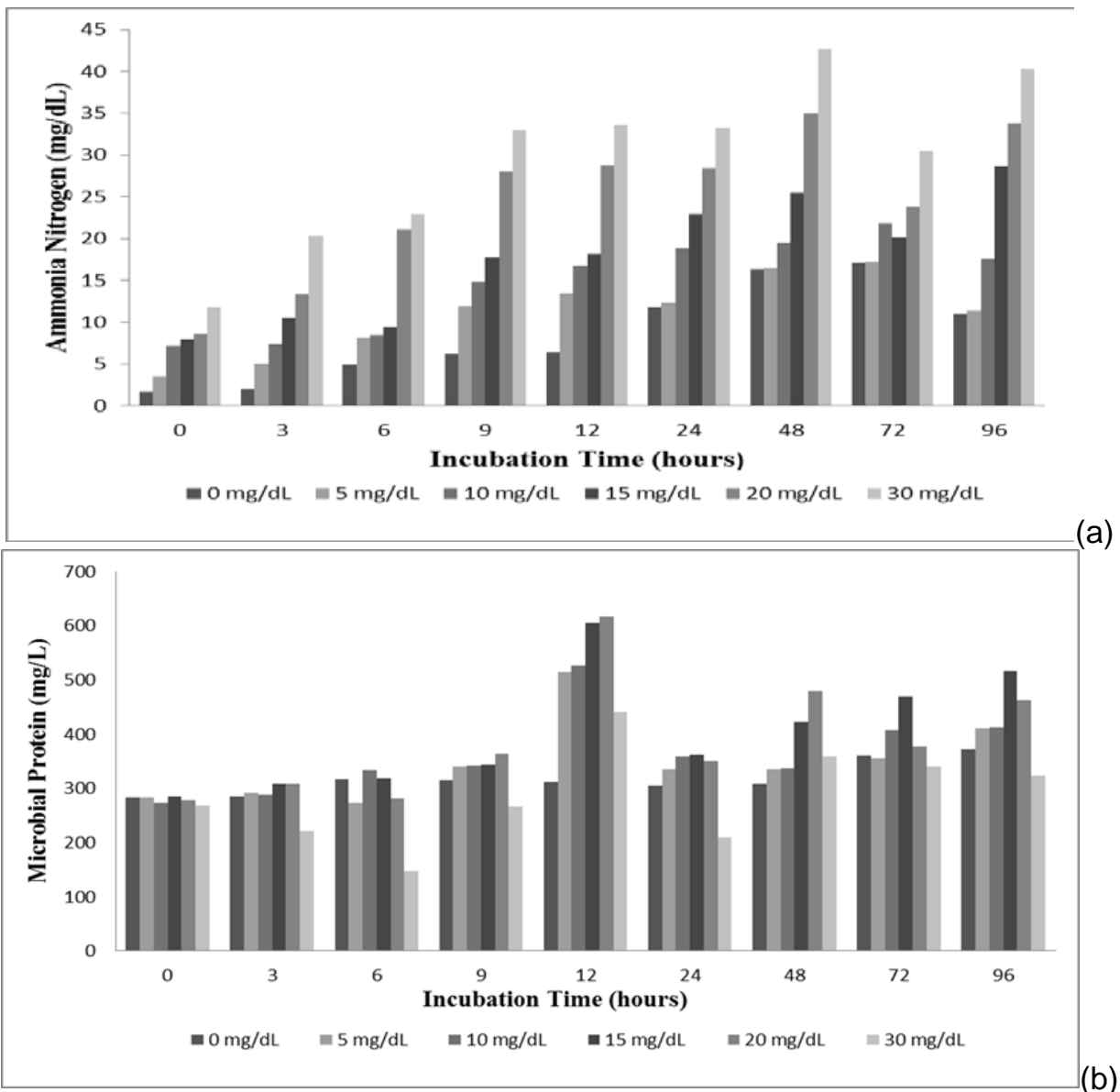

Figure 1 Effect of ammonia nitrogen levels on the concentrations of ammonia (a) and microbial protein (b) over 96 hours of in vitro incubation

Table 3 Mean of ammonia nitrogen levels on the concentration of volatile fatty acids (mM) at 48 hours of in vitro incubation

\begin{tabular}{|c|c|c|c|c|c|c|}
\hline \multirow{2}{*}{$V_{F A}{ }^{2}$} & \multicolumn{6}{|c|}{ Ammonia nitrogen $(\mathrm{mg} / \mathrm{dL})^{1}$} \\
\hline & 0 & 5 & 10 & 15 & 20 & 30 \\
\hline Acetate & 52.6 & 53.2 & 55.6 & 57.6 & 46.2 & 44.3 \\
\hline Propionate & 13.1 & 15.2 & 16.9 & 24.1 & 12.6 & 13.1 \\
\hline Butyrate & 2.3 & 2.4 & 2.5 & 2.6 & 2.6 & 2.5 \\
\hline Lactate & 0.35 & 0.35 & 0.33 & 0.38 & 0.38 & 0.32 \\
\hline$A / P^{3}$ & 4.3 & 3.5 & 3.3 & 2.5 & 3.8 & 3.9 \\
\hline Total VFA & 68 & 70.8 & 75 & 84.3 & 61.4 & 59.9 \\
\hline Indices & \multicolumn{2}{|c|}{ Regression equations } & SEM $^{4}$ & $\mathbf{L}$ & Q & $r^{2}$ \\
\hline Acetate & \multicolumn{2}{|c|}{$\hat{Y}=52.8+0.59 X-0.018 X^{2}$} & 10.92 & 0.064 & 0.043 & 0.66 \\
\hline Propionate & \multicolumn{2}{|c|}{$\hat{Y}=12.8+0.69 X-0.023 X^{2}$} & 4.96 & 0.825 & 0.012 & 0.35 \\
\hline Butyrate & \multicolumn{2}{|l|}{$\hat{Y}=2.5$} & 0.85 & 0.189 & 0.216 & - \\
\hline Lactate & \multicolumn{2}{|l|}{$\hat{Y}=0.35$} & 0.11 & 0.707 & 0.550 & - \\
\hline$A / P^{3}$ & \multicolumn{2}{|l|}{$\hat{Y}=3.5$} & 0.86 & 0.634 & 0.488 & - \\
\hline Total VFA & \multicolumn{2}{|c|}{$\hat{Y}=68.1+1.17 X-0.04 X^{2}$} & 14.49 & 0.055 & 0.001 & 0.49 \\
\hline
\end{tabular}

\footnotetext{
${ }^{1}$ Levels of rumen ammonia nitrogen; ${ }^{2} \mathrm{VFA}$ concentration in millimolar (mM); ${ }^{3}$ Acetate/propionate ratio

${ }^{4}$ SEM: standard error mean
} 
Table 4 Mean of ammonia nitrogen levels on the $\mathrm{pH}$ of the medium at 0 and 48 hours in vitro incubation

\begin{tabular}{|c|c|c|c|c|c|c|c|c|c|c|}
\hline \multirow{2}{*}{ Indices } & \multicolumn{6}{|c|}{ Ammonia nitrogen, $\mathrm{mg} / \mathrm{dL}$} & \multirow{2}{*}{ SEM $^{1}$} & \multirow{2}{*}{$r^{2}$} & \multicolumn{2}{|c|}{$P$-value } \\
\hline & 0 & 5 & 10 & 15 & 20 & 30 & & & $\mathbf{L}$ & $\mathbf{Q}$ \\
\hline \multicolumn{11}{|c|}{$\mathrm{pH}$} \\
\hline $\mathrm{Oh}$ & 6.80 & 6.83 & 6.86 & 6.87 & 6.83 & 6.83 & 0.74 & 0.56 & ns & ns \\
\hline $48 h^{2}$ & 7.64 & 7.55 & 7.53 & 7.48 & 7.44 & 7.33 & 0.48 & 0.96 & 0.001 & ns \\
\hline
\end{tabular}

${ }^{1}$ SEM: Standard error mean; ${ }^{2} \hat{Y}=7.63-0.009 X$

Table 5 describes the microbial growth-related parameters on NDF. In the treatment with $15 \mathrm{mg} / \mathrm{dL}$ of ammonia nitrogen, the addition of an NPN source increased the specific growth rate of the microorganisms by $2.6 \%$ to $20.1 \%$ and microbial growth efficiency on pdNDF by $5 \%$. This represents $293.3 \mathrm{~g}$ of microbial $\mathrm{DM} / \mathrm{kg}$ of degraded carbohydrate in relation to $0 \mathrm{mg} / \mathrm{dL} \mathrm{NH}_{3}-\mathrm{N}$ in the rumen fluid, which presented $278.4 \mathrm{~g}$ microbial DM/kg of degraded carbohydrate.

Table 5 Secondary parameters associated with microbial growth on the potentially degradable neutral detergent fibre in each treatment

\begin{tabular}{lcccccc}
\hline \multirow{2}{*}{ Indices } & \multicolumn{7}{c}{ Ammonia nitrogen $\mathbf{( m g / d L ) ~}$} \\
\cline { 2 - 7 } & $\mathbf{0}$ & $\mathbf{5}$ & $\mathbf{1 0}$ & $\mathbf{1 5}$ & $\mathbf{2 0}$ & $\mathbf{3 0}$ \\
\hline$\mu^{1}$ & 2.29 & 2.35 & 2.58 & 2.92 & 2.68 & 2.37 \\
SGR & 0.0458 & 0.0470 & 0.0504 & 0.0550 & 0.0524 & 0.0474 \\
EMG & 278.42 & 280.59 & 286.36 & 293.33 & 289.35 & 281.30
\end{tabular}

\footnotetext{
${ }^{1} \mu$ : maximum degradation rate (/h); SGR: specific microorganism growth rate (/h); EMG: efficiency of microbial growth on pdNDF (g microbial DM/kg degraded carbohydrate)
}

The largest effectively degraded fractions were observed in the treatment with $15 \mathrm{mg} / \mathrm{dL}$ at the various passage rates (Table 6). That treatment was $11.1 \%$ more efficient compared with the medium without urea considering the passage rate of $0.020 / \mathrm{h}$, at which the highest percentage degradation of pdNDF was observed. In absolute values, the treatment with $15 \mathrm{mg} / \mathrm{dL}$ of rumen ammonia nitrogen provided the highest estimates of the effectively degraded fraction of pdNDF for the various rates of passage. These results follow the patterns of the other variables, since this parameter derives from the degradation rate of pdNDF.

Table 6 Estimates of the effectively degraded fraction of potentially degradable neutral detergent fibre (\% of pdNDF) in each treatment

\begin{tabular}{lccc}
\hline & & ${\text { Rumen passage rate }(/ \mathbf{h})^{\mathbf{1}}}$ \\
\cline { 2 - 4 } Treatment & $\mathbf{0 . 0 2 0}$ & $\mathbf{0 . 0 3 5}$ & $\mathbf{0 . 0 5 0}$ \\
\hline $0 \mathrm{mg} / \mathrm{dL}$ & 37.11 & 30.47 & 25.46 \\
$5 \mathrm{mg} / \mathrm{dL}$ & 37.45 & 30.87 & 25.88 \\
$10 \mathrm{mg} / \mathrm{dL}$ & 38.90 & 32.41 & 27.43 \\
$15 \mathrm{mg} / \mathrm{dL}$ & 41.23 & 34.80 & 29.77 \\
$20 \mathrm{mg} / \mathrm{dL}$ & 39.32 & 32.95 & 28.01 \\
$30 \mathrm{mg} / \mathrm{dL}$ & 37.43 & 30.90 & 25.94
\end{tabular}

\footnotetext{
${ }^{1}$ Assuming ruminal displacement flow kinetics of solids with gamma-1 distribution
} 
Table 7 Estimates of rumen degradation parameters of potentially degradable neutral detergent fibre and asymptotic standard deviations in each treatment

\begin{tabular}{lcccccc}
\hline \multirow{2}{*}{ Indices $^{\mathbf{1}}$} & \multicolumn{7}{c}{ Ammonia nitrogen (mg/dL) } \\
\cline { 2 - 7 } & $\mathbf{0}$ & $\mathbf{5}$ & $\mathbf{1 0}$ & $\mathbf{1 5}$ & $\mathbf{2 0}$ & $\mathbf{3 0}$ \\
\hline$\lambda(/ \mathrm{h})$ & 0.1247 & 0.1278 & 0.1372 & 0.1497 & 0.1424 & 0.1290 \\
$\mathrm{C}^{\prime}(/ \mathrm{h})^{1}$ & 0.0743 & 0.0762 & 0.0818 & 0.0892 & 0.0849 & 0.0769 \\
$\mathrm{RVDR}(\%)^{2}$ & 100 & 102.5 & 110.1 & 120.1 & 114.3 & 103.5 \\
$\mathrm{~L}(\mathrm{~h})$ & 13.78 & 13.44 & 12.52 & 11.47 & 12.06 & 13.32 \\
$\mathrm{ASD}$ & 7.41 & 8.07 & 8.25 & 8.69 & 9.06 & 8.65 \\
& & & & & & \\
\hline
\end{tabular}

$c^{\prime}$ : fractional rate of degradation obtained from the conversion of parameter $\lambda$; RVDR: relative value of the degradation rate; L: discrete lag time; ASD: asymptotic standard deviation.

${ }^{1}$ Estimated according to gamma-2 distribution properties: $c^{\prime}: 0.59635 \lambda$

${ }^{2}$ Relative value of the degradation rate in relation to the forage $(0 \mathrm{mg} / \mathrm{dL})$

In the present study, the ammonia nitrogen concentration of $30 \mathrm{mg} / \mathrm{dL}$ is above the values deemed optimal. The degradation of NDF at the end of the incubation period had a quadratic response, with its maximum point at around $17.76 \mathrm{mg} / \mathrm{dL}$, based on the derivative of the equation (Figure 2).

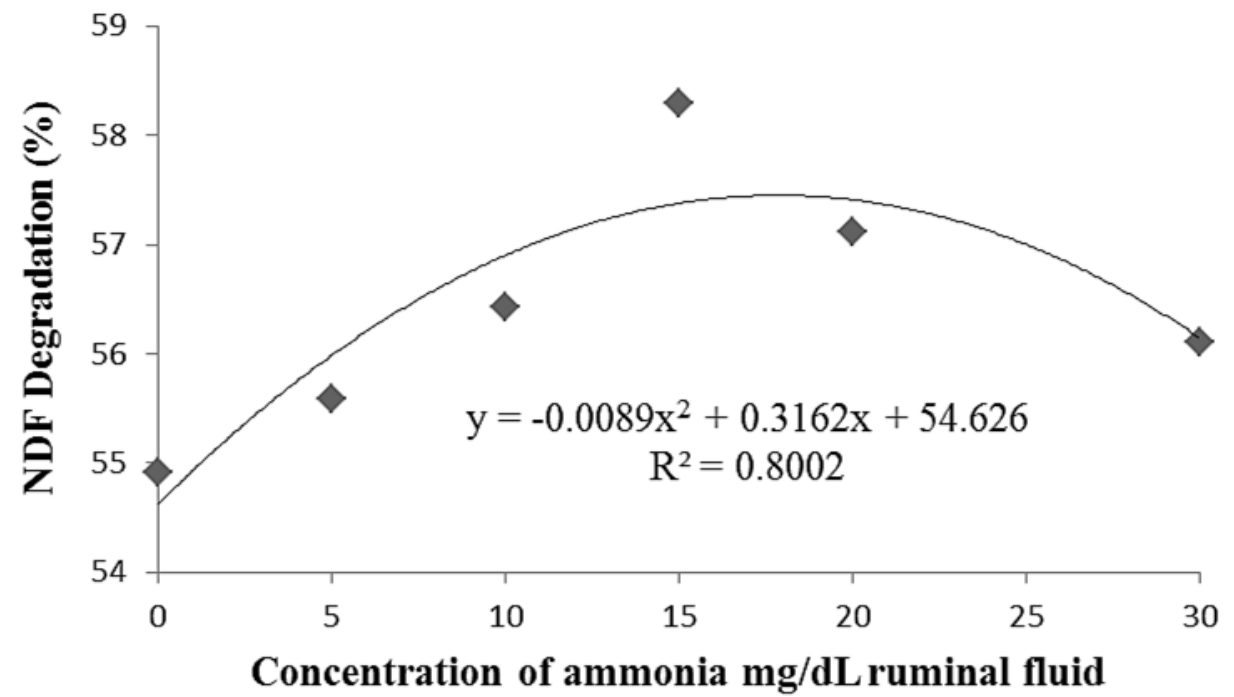

Figure 2 Neutral detergent fibre degradation (\%) in relation to the experimental levels of ammonia nitrogen

\section{Discussion}

At the lowest levels of ammonia $\left(0 \mathrm{mg}\right.$ and $\left.5 \mathrm{mg} \mathrm{NH}_{3}-\mathrm{N} / \mathrm{dL}\right)$, part of the protein from buffel grass was probably deaminated in the rumen by the action of proteolytic enzymes, which decomposed it into ammonia. Increased ammonia production is also associated with a rise in the $\mathrm{pH}$ of the medium, which potentiates the deamination activity and consequently increases ammonia production (Lana et al., 1998). At the start of fermentation, most of the protein that is present in the forage is in undegraded form. During the fermentation process there is a reduction of protein nitrogen and a considerable increase in $\mathrm{NH}_{3}-\mathrm{N}$ caused by proteolysis and deamination of proteins and amino acids. The insoluble but potentially degradable protein of feeds is converted to ammonia (Danley \& Vetter, 1973; Lana et al., 2007).

The optimum point for efficiency of microbial protein synthesis was when $19.11 \mathrm{mg} / \mathrm{dL}$ of $\mathrm{NH}_{3}-\mathrm{N}$ was present in the growth medium. After that level, microbial growth in the medium was inhibited. This concentration is above the approximate $3.3 \mathrm{mg} / \mathrm{dL}$ that is recommended by Hoover (1986) for the start of microbial growth, and meets the minimum requirements of the microbial population. However, it is below the $23 \mathrm{mg} / \mathrm{dL}$ that was defined by Mehrez et al. (1977) for attaining the maximum potential of microbial protein synthesis in sheep. 
Indeed, the slow release of NPN from buffel grass limited microbial growth. Hay made from this grass may contain around $44.5 \%$ of CP in the form of NPN (Cabral, 2014), and part of this NPN is insoluble, as it is associated with the lignin on the cell wall. For this reason, it is poorly available for the digestive process in ruminants (Bezerra et al., 2014; Fribourg, 1985).

Because of their high solubility in the ruminal medium, chemical sources of NPN such as urea may release harmful levels of ammonia in the rumen, which may reduce rumen microbial activity (Arelovich et al., 2000).

Satter \& Slyter (1974) declared that VFA production is reduced slightly under limited levels of rumen ammonia nitrogen. However, at concentrations greater than $5 \mathrm{mg} / \mathrm{dL}$, no significant effect occurs on the relative quantities of VFA produced. Imaizumi et al. (2002), on the other hand, inferred that $5 \mathrm{mg} / \mathrm{dL}$ rumen ammonia nitrogen is insufficient to obtain maximum rumen microbial activity in the rumen, since the mean $\mathrm{NH}_{3}-\mathrm{N}$ values observed in their study for maximum fibre degradation were between 10.91 and $15.29 \mathrm{mg} / \mathrm{dL}$. In the present study, in the medium without urea, there was low microbial growth (Table 2). Only after 24 hours of incubation and after the release of ammonia contents greater than $15 \mathrm{mg} / \mathrm{dL}$ did slow microbial growth start (Figure 1b).

The rapid hydrolysis of urea that is associated with the elevated $\mathrm{pH}$ values that was found in the present study (Table 4) was responsible for the high rumen ammonia nitrogen values. Higher rumen $\mathrm{pH}$ and dietary urea levels supposedly lead to higher concentrations of $\mathrm{NH}_{3}-\mathrm{N}$ owing to greater ureolytic activity prompted by the rise of rumen $\mathrm{pH}$ that results from the rapid action of urease, which ultimately accelerates the hydrolysis of urea (Froslie, 1977). According to Mahadevan et al. (1976), the ideal pH for maximum activity of the urease enzyme is between 7.09 and 8.5. The current $\mathrm{NH}_{3}-\mathrm{N}$ data at 48 hours corroborate this assertion, since the highest concentrations were obtained at that time, during the 96 hours of incubation (Figure 1), coinciding with $\mathrm{pH}$ values above 7.0 (Table 4).

However, greater NDF degradability can be attributed to adherence and colonization rather than to the specific activity of bacterial enzymes. Farenzena et al. (2013) and Rasmussen et al. (1989) did not observe any effects of $\mathrm{pH}$ changes between 6.0 and 8.0 on microbial adherence. Additionally, according to De Veth \& Kolver (2001), NDF degradation declines when the rumen pH remains for four hours at values below 6.0 and microbial synthesis decreases when the $\mathrm{pH}$ remains below this value for 12 hours. In the present study, the $\mathrm{pH}$ was not below 6.0 in any of the experimental times. It remained in the adequate range for the activity of rumen cellulolytic microorganisms (Mould et al., 1983; Russell et al., 1992).

The estimates of rumen degradation parameters of pdNDF (Table 5) revealed mathematical indeterminacy between parameters $c$ and $p$, which tended towards the same estimate, according to Equation I. In this case, no differentiation was observed between the measures, and thus the proposed model was unavoidably re-parametrized (Van Milgen et al., 1991) with the adoption of a combined rate of lag time and degradation: $\lambda$ (Equation II). According to Costa et al., (2008), it is not possible to obtain biological comparisons by directly applying parameters $c$ and $\lambda$. The latter parameter is thus converted to $c^{\prime}$ form (Equation III), which indicates a higher relative degradation rate value.

Detmann et al., (2011) stated that improvements in NDF degradation result from the addition of nitrogenous compounds to the diet, which makes it easier for the microorganisms in the rumen environment to utilize these compounds to synthesise enzyme complexes, which explains the increase in the pdNDF rates. In the current experiment, this assertion was confirmed by the discrete lag time (Table 5), according to which the time for the onset of effective degradation of NDF was shortest in the treatment with $15.0 \mathrm{mg} / \mathrm{dL}$ of ammonia nitrogen.

The presence of a source of rapidly degraded carbohydrates (e.g. starch and pectin) in the incubation medium may improve the utilization of the supplied ammonia, reducing its excess in the medium. According to Detmann et al., (2005), high levels of urea addition favour the formation of ammonia in the rumen, while low levels of energy that are rapidly available in the rumen may lead to low microbial protein yield and consequently poor NDF degradation. This rapidly fermenting energy lowers the $\mathrm{pH}$, preserving the molecule in the form of ammonium, which reduces ammonia losses. Therefore, the rumen $\mathrm{pH}$ decline observed with the supply of rapidly degraded carbohydrates is beneficial to the ionization of ammonia, resulting in smaller losses.

Even higher levels of rumen ammonia nitrogen in the incubation medium did not lead to higher degradation rates of NDF. Literature results differ in terms of the level that optimizes fibre fermentation in the rumen.

However, the improvement that was observed in the degradation rate of pdNDF that was provided by the addition of nitrogenous compounds confirms the need to supply NPN sources in situations in which the basal diet is primarily low-protein forage such as buffel grass in an advanced maturity stage. In this situation, to obtain energy from the microbial degradation of fibrous carbohydrates, sources of nitrogenous compounds 
are necessary for the synthesis of the enzyme complexes of rumen microorganisms (Detmann et al., 2009; Lazzarini et al., 2009; Sampaio et al., 2009) and for microbial protein synthesis.

Discrete lag time decreased gradually as the ammonia concentration in the medium was increased up to $30 \mathrm{mg} / \mathrm{dL}$. The lowest estimate for this variable was observed in the treatment with $15 \mathrm{mg} / \mathrm{dL}$ of ammonia in the rumen fluid. Discrete lag time is a measure that is used to estimate the time required for the events preceding the degradation activities such as particle hydration, adherence to the substrate, colonization, and biofilm formation for enzyme production. Therefore, a reduction in lag time confirms that the medium has become more prone to microbial cell multiplication with the inclusion of nitrogenous compounds (Detmann et al., 2009).

Although the improvements in microbial growth were slight, the present results are superior to those reported by Costa et al. (2008) and Detmann et al. (2011), who evaluated the effects of various sources of nitrogenous compounds on NDF degradation. This may indicate greater enzyme availability for the degradation of the basal fibre at these concentrations. Satter \& Roffler (1979) claimed that the minimum concentration of rumen ammonia nitrogen should be around $5 \mathrm{mg} / \mathrm{dL}$ rumen fluid so that microbial fermentation is not compromised. This value was attained at all levels, and also when buffel grass was used alone. Mehrez et al. (1977), on the other hand, recommended the concentration of $23 \mathrm{mg} / \mathrm{dL}$ for maximum microbial synthesis. In the present study, the maximum efficiency of microbial growth on pdNDF was fachieved at $15 \mathrm{mg} / \mathrm{dL}$ of ammonia nitrogen in the rumen fluid. This difference can be explained by the different animal species that were used in the studies. The microbial flora of sheep are better adapted to fibre degradation, resulting in greater utilization of ammonia for microbial synthesis (Henderson et al., 2015) compared with goats.

Lazzarini et al. (2009) stated that basal diets for ruminants should contain at least $7 \% \mathrm{CP}$, which is the minimum necessary for the rumen microorganisms to be able to utilize the potentially degradable fibrous substrates in low-quality tropical forages. This statement does not agree with the increase observed in the effectively degraded fraction of pdNDF in the present trial, since the minimum quantity of nitrogenous compounds was partially provided by the treatment that contained only forage with $4.98 \%$ CP (Table 1 ). Because the nitrogen requirement was met, this could be attributed to the forages being preserved in hay form, which contained $15 \%$ to $25 \%$ NPN, which was responsible for ensuring minimum ammonia nitrogen levels to the bacterial population in the treatment with $0 \mathrm{mg} / \mathrm{dL}$. However, microbial growth and the time that is necessary for fibre degradation to begin (discrete lag) were much lower in the treatments in which the medium contained urea. Considering that the rumen is an open system with constant input and output of substances, the lower speeds of colonization and fibre degradation in the absence of nitrogen sources besides the buffel grass itself may inhibit fibre digestion in the animal.

A lack of nitrogenous compounds in diets may cause deleterious effects on animal performance when these compounds do not meet the microbial requirements. It may not only slow the rate of utilization, but impose limits on the extent of NDF degradation. Additionally, it may compromise cellular proliferation and microorganism activity, leading to decreased utilization of fibre, followed by decreased dry matter intake, and, ultimately, poor animal performance (Detmann et al., 2009; Figueiras et al., 2010).

According to Detmann et al. (2011), in in vitro trials, the ammonia nitrogen recycling mechanisms are not present, as occurs in the in vivo rumen environment. Thus, results derived from in vitro experiments may yield lower or higher ammonia nitrogen values for optimized digestion of low-protein and high-NDF forages compared with the actual use of an animal. However, rumen microorganisms tend to behave similarly in vitro and in vivo (Gonçalves et al., 2001), which suggests that the presence of NPN in the form of ammonia stimulates the growth of fibrous carbohydrate-fermenting microorganisms and, consequently, potentiates the ruminal digestion of NDF.

\section{Conclusion}

Urea improves the degradation dynamics of NDF fibre from deferred buffel grass, increasing the concentrations of acetate and propionate. The optimum level of ammonia nitrogen for maximum in vitro degradation of the NDF from deferred buffel grass by rumen microorganisms from goats is $17.76 \mathrm{mg} / \mathrm{dL}$. For maximum acetate and propionate production, the recommended ammonia nitrogen levels in the medium are 16.4 and $15 \mathrm{mg} / \mathrm{dL}$, respectively. The addition of a rapidly degradable carbohydrate source may optimize the utilization of the ammonia generated by the addition of urea.

\section{Authors' Contributions}

JSA, EMS and CJB designed the study and conducted statistical analyses of the data. JASN, RMAP, CASS and ECBC collected data, performed laboratory analysis and wrote the manuscript.

\section{Conflict of Interest Declaration}

The authors declare that they have no competing interests. 


\section{References}

Arelovich H.M., Owens, F.N., Horn, G.W. \& Vizcarra, J.A., 2000. Effects of supplemental zinc and manganese on ruminal fermentation, forage intake, and digestion by cattle fed prairie hay and urea. J. Anim. Sci. 78, 2972-2979.

Association of Official Analytical Chemists (AOAC), 2012. Official methods of analysis. 19th ed. Gaithersburg, MD, USA. pp. 2610.

Beuvink, J.M.W. \& Kogut, J., 1993. Modeling gas production kinetics of grass silages incubated in ruminal fluid. J. Anim. Sci. 71, 1041-1046.

Bezerra, H.F.C., Santos, E.M., Oliveira, J.S., Pinho, R.M.A., Perazzo, A.F., Silva, A.P.G., Ramos, J.P.F. \& Pereira, G.A., 2014. Fenos de capim-buffel amonizados com ureia. Revista Brasileira de Saúde e Produção Animal 15, 561-569. (in Portuguese, English abstract).

Bradford, M.M., 1976. A rapid and sensitive method for the quantitation of microgram quantities of protein utilizing the principle of protein-dye binding. Anal. Biochem. 72, 248-254.

Cabral, J.E.S., 2014. Fracionamento do nitrogênio e dos carboidratos de plantas encontradas na caatinga no Rio Grande do Norte. Dissertação (Mestrado em Mestrado em Produção Animal, Universidade Federal Rural do Semi-Árido. pp.55 (in Portuguese, English abstract).

Campos, P.R.S.S., Valadares Filho, S.C., Cecon, P.R., Detmann, E., Leão, M.I., Souza, S.M., Lucchi, B.B. \& Valadares, R.F.D., 2006. Estudo comparativo da cinética de degradação ruminal de forragens tropicais em bovinos e ovinos. Arquivo Brasileiro de Medicina Veterinária e Zootecnia 58, 1181-1191 (in Portuguese, English abstract).

Chaney, A.L. \& Marbach, E.P., 1962. Modified reagents for determination of urea and ammonia. Clin. Chem. 8, 130-132.

Costa, V.A.C., Detmann, E., Valadares Filho, S.C., Paulino, M.F., Henriques, L.T. \& Mantovani, H.C., 2008. Degradação in vitro da fibra em detergente neutro de forragem tropical de baixa qualidade em função de suplementação com proteína e/ou carboidratos. Revista Brasileira de Zootecnia 37, 494-503 (in Portuguese, English abstract).

Cysneiros, C.S.S., Ferreira, R.N., Oliveira, M.A., Favoretto, A.O., Arnhold, E. \& Ulhoa, C.J., 2013. Produção, caracterização e avaliação de enzimas fibrolíticas na digestibilidade da forragem de milho. Ciência Animal Brasileira 14, 426-435 (in Portuguese, English abstract).

Danley, M.M. \& Vetter, R.L., 1973. Change in carbohydrate and nitrogen fraction and digestibility of forages: maturity and ensiling. J. Anim. Sci. 37, 994-999.

Detmann, E., Queiroz, A.C., Zorzi, K., Mantovani, H.C., Bayão, G.F.V. \& Gomes, M.P.C., 2011. Degradação in vitro da fibra em detergente neutro de forragem tropical de baixa qualidade em função da suplementação com proteína verdadeira e/ou nitrogênio não-proteico. Revista Brasileira de Zootecnia 40, 1272-1279. (in Portuguese, English abstract).

Detmann, E., Paulino, M.F., Mantovani, H.C., Valadares Filho, S.C., Sampaio, C.B., Souza, M.A., Lazzarini, I. \& Detmann, K.S.C., 2009. Parameterization of ruminal fibre degradation in low-quality tropical forage using Michaelis-Menten kinetics. Livest.Sci. 126, 136-146.

Detmann, E., Paulino, M.F., Valadares Filho, S.C., Cecon, P.R., Zervoudakis, J.T., Cabral, L.S., Gonçalves, L.C. \& Valadares, R.F.D., 2005. Níveis de proteína em suplementos para terminação de bovinos em pastejo durante o período de transição seca/águas: Digestibilidade aparente e parâmetros do metabolismo ruminal e dos compostos nitrogenados. Revista Brasileira de Zootecnia 34, 1380-1391 (in Portuguese, English abstract).

De Veth, M.J. \& Kolver, E.S., 2001. Diurnal variation in pH reduces digestion and synthesis of microbial protein when pasture is fermented in continuous culture. J. Dairy Sci. 84, 2066-2207.

Ellis, W.C., Matis, J.H., Hill, T.M. \& Murphy, M.R., 1994. Methodology for estimating digestion and passage kinetics of forages. In: J.R. Fahey (ed.) Forage Quality, Evaluation, and Utilization. American Society of Agronomy, Madison, WI. pp. 682-756.

Farenzena, R., Kozloski, G.V., Mezzomo, M.P. \& Fluck, A.C., 2013. Forage degradability, rumen bacterial adherence and fibrolytic enzyme activity in vitro: Effect of pH or glucose concentration. J. Agric. Sci. 152, 325-332.

Figueiras, J.F., Detmann, E., Paulino, M.F., Valente, T.N.P., Valadares Filho, S.C. \& Lazzarini, I., 2010. Intake and digestibility in cattle under grazing supplemented with nitrogenous compounds during dry season. Revista Brasileira de Zootecnia 39, 1303-1312.

Fribourg, H.A., 1985. Summer annual grasses. In: Forages - The Science of Grassland Agriculture. Ed: M.E. Heath, R.F. Barnes \& D.S. Metcalfe, lowa State University, Ames.

Froslie, A., 1977. Feed-related urea poisoning in ruminants. Folia Veterinary Latina, 7, 17-37.

Gonçalves, A.L., Lana, R.P., Rodrigues, M.T., Vieira, R.A.M., Queiroz, A.C. \& Henrique, D.S., 2001. Degrabilidade ruminal da matéria seca e da fibra em detergente neutro de alguns volumosos utilizados na alimentação de cabras leiteiras, submetidas a dietas com diferentes relações volumoso: concentrado. Revista Brasileira de Zootecnia 30, 1893-1903. (in Portuguese, English abstract).

Henderson, G., Cox, F., Ganesh, S., Jonker, A., Young, W. \& Janssen, P.H., 2015. Rumen microbial community composition varies with diet and host, but a core microbiome is found across a wide geographical range. Scientific Reports 5, 1-15.

Imaizumi, H., Santos, F.A.P., Pires, A.V., Nussio, C.M.B., Barnabé, E.C. \& Juchem, S.O., 2002. Avaliação de diferentes fontes e teores de proteína na dieta sobre o desempenho, fermentação ruminal e parâmetros sangüíneos de vacas da raça Holandesa em final de lactação. Acta Scientiarum 24, 1031-1037 (in Portuguese, English abstract).

Lana, R.P., Russell, J.B. \& Amburgh, M.E.V., 1998. The role of pH in regulating ruminal methane and ammonia production. J. Anim. Sci. 76, 2190-2196.

Lana, R.P., Leopoldino, W.M., Oliveira, J.S., Veloso, R.G., Nunes, P.M.M. \& Queiroz, A.C., 2007. Parâmetros da degradação protéica ruminal de diferentes alimentos e rações estimados por técnica in vitro. Arquivo Brasileiro de Medicina Veterinária e Zootecnia 59, 414-422 (in Portuguese, English abstract). 
Lazzarini, I., Detmann, E., Sampaio, C.B., Paulino, M.F., Valadares Filho, S.C., Souza, M.A. \& Oliveira, F.A., 2009. Dinâmicas de trânsito e degradação da fibra em detergente neutro em bovinos alimentados com forragem tropical de baixa qualidade e compostos nitrogenados. Arquivo Brasileiro de Medicina Veterinária e Zootecnia, 61, 635-647. (in Portuguese, English abstract).

Licitra, G., Hernandez, T.M. \& Van Soest, P.J., 1996. Standardization of procedures for nitrogen fractionation of ruminant feeds. Anim. Feed Sci. Technol. 57, 347-358.

Mahadevan, S., Sauer, F. \& Erfle, J.D., 1976. Studies on bovine rumen bacterial urease. J. Anim. Sci. 42, 745-753.

Mehrez, A.Z., Ørskov, E.R. \& McDonald, I., 1977. Rates of rumen fermentation in relation to ammonia concentration. Br. J. Nutr. 38, 437-443

Moreira, J.N., Lira, M.A., Santos, M.V.F., Araújo, G.G.L. \& Silva, G.C., 2007. Potencial de produção de Capim-buffel na época seca no semi-árido pernambucano. Revista Caatinga, 20, 20-27 (in Portuguese, English abstract).

Mould, F.L., Ørskov, E.R. \& Manns, O., 1983. Associative effects of mixed feeds. I. Effects of type and level of supplementation and the influence of the rumen $\mathrm{pH}$ on cellulolysis in vivo and dry matter digestion of various roughages. Anim. Feed Sci. Technol. 10, 15-30.

Oliveira, J.S., Queiroz, A.C., Mantovani, H.C., Bayão, G.F.V., Detmann, E., Santos, E.M. \& Silva, T.C., 2012. Avaliação do soro fermentado por Enterococcus faecium em consórcio com Veilonella parvula na alimentação de ruminantes. Revista Brasileira de Zotecni 41, 172-180. (in Portuguese, English abstract).

Ørskov, E.R. \& McDonald, I., 1979. The estimation of protein degradability in the rumen from incubation measurements of feed in weighted according to rate passage. J. Agric. Sci. 92, 499-503.

Rasmussen, M.A., White, B.A. \& Hespell, R.B., 1989. Improved assay for quantitating adherence of ruminal bacteria to cellulose. Appl. Environ. Microbiol. 55, 2089-2091.

Russell, J.B. \& Martin, S.A., 1984. Effects of various methane inhibitors on the fermentation of amino acids by mixed rumen micorganisms in vitro. J. Anim. Sci. 59, 1329-1338.

Russell, J.B., O'Connor, J.D., Fox, D.G., Van Soest, P.J. \& Sniffen, C.J., 1992. A net carbohydrate and protein system for evaluating cattle diets: I. Ruminal fermentation. J. Anim. Sci. 70, 3551-3561.

Sampaio, C.B., Detmann. E., Lazzarini, I., Souza, M.A., Paulino, M.F. \& Valadares Filho, S.C., 2009. Rumen dynamics of neutral detergent fiber in cattle low-quality tropical forage and supplemented with nitrogenous compounds. Revista Brasileira de Zootecnia 38, 560-569.

Santos, G.R.A., Guim, A., Santos, M.V., Ferreira, M.A., Lira, M.A., Dubeux Júnior, J.C.B. \& Silva, M.J., 2005. Caracterização do pasto de Capim-buffel diferido e da dieta de bovinos, durante o período seco no sertão de Pernambuco. Revista Brasileira de Zootecnia 34, 454-463 (in Portuguese, English abstract).

Satter, L.D. \& Slyter, L.L., 1974. Effect of ammonia concentration on rumen microbial production in vitro. Br. J. Nutr. 32, 199-208.

Satter, L.D. \& Roffler, R.E., 1979. Nitrogen requirement and utilization in dairy cattle. J. Dairy Sci. 58, 1212-1237.

Sniffen, C.J., O'Connor, J.D., Van Soest, P.J., Fox, D.G. \& Russell, J.B., 1992. A net carbohydrate and protein system for evaluating cattle diets: Carbohydrate and protein availability. J. Anim. Sci. 70, 3562-3577.

Van Milgen, J., Murphy, L.L. \& Berger, LL., 1991. A compartmental model to analyze ruminal digestion. J. Dairy Sci. 74, 2515-2529.

Van Soest, P.J., 1967. Development of a comprehensive system of feeds analysis and its applications to forages. J. Anim. Sci. 26, 119-128.

Van Soest, P.J., 1994. Nutritional Ecology of the Ruminant. 2nd edition. Cornell University Press, Ithaca. pp. 476.

Vieira, R.A.M., Pereira, J.C., Malafaia, P.A.M. \& Queiroz, A.C., 1997. The influence of elephant grass (Pennisetum purpurem Schum. Mineiro variety) growth on the nutrient kinetics in the rumen. Anim. Feed Sci. Technol. 66, $197-210$ 